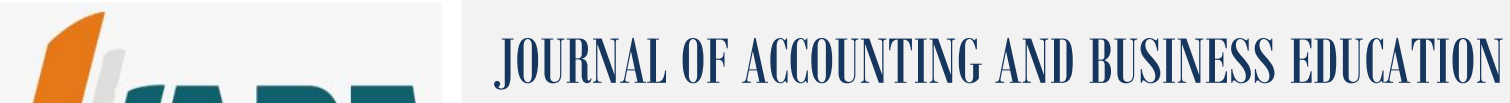 P-ISSN 2528-7281 E-ISSN 2528-729X \\ E-mail: jabe.journal@um.ac.id \\ http://journal2.um.ac.id/index.php/jabe/
}

\section{The Use of Outsourced Accounting Service and Its Impact on SMEs Performance}

\author{
Fadilla Cahyaningtyas ${ }^{1}$ \\ Mega Noerman Ningtyas ${ }^{2}$ \\ ${ }^{1,2}$ Accounting Department, Sekolah Tinggi Ilmu Ekonomi Asia Malang, Indonesia \\ e-mail: fadilla_cahyaningtyas@yahoo.co.id
}

DOI: http://dx.doi.org/10.26675/jabe.v4i2.8641

\begin{abstract}
This research was about the important contribution of SMEs to Indonesian economy in reality and their weak management accounting functions. This research aimed to find out the factors influencing SMEs' decision to use outsourced accounting advisory services and the effect of such use towards SMEs' performance as from Transaction Cost Economics (TCE) and Resource Based View (RBV) perspectives. In this research, the population was comprised of manufacturing SMEs ini Malang. The researchers then took the sample using purposive sampling method. Meanwhile, the criteria to determine the sample were based on the definition of SME in Indonesia. Furthermore, the researchers conducted survey by distributing 270 questionnaires to collect the data. Using SEM (AMOS) analysis, the researchers successfully figured out that asset specification, environment uncertainty, technical competence, and competition level acted as major factors that affected SMEs' decision to use outsourced accounting services. Meanwhile, the researchers found that behavior uncertainty and trust in accountants did not have significant impact on such SMEs' decision. The result of SEM analysis showed that outsourced accounting advisory services significantly provided positive effect on SMEs' performance.
\end{abstract}

Keywords: SMEs, Outsourced Accounting, Transaction Cost Economics (TCE), Resource Based View (RBV), Performance

\section{INTRODUCTION}

Company performance has been one of the most-studied topics, be it private or state-owned enterprises, in which it consists of two components, namely financial and non-financial performances (Tazilah, Majid, \& Suffari, 2019). Even in Indonesia studies on a company's performance analysis have been massively done in accounting field. However, most of these studies on performance analysis focus on major companies when in reality, looking at it a little bit closer, the existence of and roles played by Small and Medium Enterprises (SMEs) are dominant in the economy than major companies. For five years in a row (2013 - 2017), the domination of SMEs are shown by the percentage of SME existence which reaches $99.99 \%$ each year, and major businesses (UB) only 0.01\% (Kemenkop, 2017). The SMEs' contribution to the absorption of manpower is also far greater than major businesses, i.e. at $97 \%$ of the total manpower. Likewise, SMEs could significantly contribute to Gross Domestic Product (PDB) over 55\% each year (Kemenkop, 2017).

This SMEs' contribution helps increase the country's economic development and growth significantly (Mwangi, Mutiso, \& Mungai, 2018). As the importance of SMEs' role grows in the economic growth and development, many challenges should be dealt with by SMEs. One of them is the unstable and 
unpredictable business environment as a result of technology changes, increased customer's demand, and tight competition (Kamyabi \& Devi, 2011b). Furthermore, in such a business environment, SMEs' continuance is under a threat and SMEs have been continuously forced to face these significant challenges (Ganesan, Haron, Amran, \& Pitchay, 2018; Kamyabi \& Devi, 2011a).

Even in Indonesia, SMEs still find it difficult to deal with this business environment challenge. One of the difficultires is the involvement in performing an accounting cycle, ranging from recording to measuring or assessing the activities taking place in their businesses, to preparing financial statements. This is consistent with the result of a previous study which finds that SMEs are likely to find it difficult to manage and control their internal system well in order to prepare sound financial statements (Tazilah et al., 2019). Many factors contribute to this SMEs' difficulty in preparing financial statements, including their lack of adequate resources, both financial and non-financial ones (Hidayati, 2013). If this continues, it is not impossible that SMEs might fail to keep their businesses going in this increasingly more competitive business environment.

To overcome this issue, some studies suggest that SME needs to use outsourced accounting service to perform its accounting function (Carey, 2015; Ganesan et al., 2018; Husin \& Ibrahim, 2014; Jayabalan, Dorasamy, Ramlan, \& Ching, 2009; Kamyabi \& Devi, 2011d; Kotabe \& Mol, 2009). Previous studies recommend SME to use outsourcing services to change its traditional activities, particularly in its accounting function (Cullinan \& Zheng, 2017; Kotabe \& Mol, 2009). Outsourced accounting service is an option for SMEs to maintain its competitive advantage and in a competitive environment (Jayabalan et al., 2009; Kipsang \& Mwangi, 2017). SMEs need the consultation and expertise related to accounting practice to improve its performance (Husin \& Ibrahim, 2014). Outsourced service can benefit SMEs' competence, enabling them to save their costs more effectively and efficiently (Agburu, Anza, \& Iyortsuun, 2017; Rodriguez \& Fierro, 2016), improve their responsiveness to business environment changes, and lower the risks posed by technology change (Agburu et al., 2017). For these reasons, outsourced accounting service is used extensively and it is believed these outsourced accountants can be professional advisors among SMEs (Blackburn, Carey, \& Tanewski, 2018).

However, the awareness of using external accounting services to deal with their accounting system implementation issues still low. This is disclosed by a previous study which finds that the bookkeeping in Kenyan SMEs is inadequate and these SMEs rarely use high-quality outsourced accounting services (Kipsang \& Mwangi, 2017). The same phenomenon is also found in Indonesia. A previous study finds that out of 70 SMEs which are taken as respondents, 50 want to have bookkeeping, yet only 18 respondents wish to use consultant service for their accounting issues (Hidayati, 2013).

Based on the phenomenon above, the researchers are urged to conduct research on such topic as the use of outsourced accounting service and its impact on SMEs' performance since not many studies have been carried on this topic in Indonesia. This research is a replication of a previous study in a different country (Kamyabi \& Devi, 2011d, 2011b), in which the previous uses Transaction Economis Cost (TCE) and Resource Based View (RBV) theories to test the factors which affect the SMEs' tendency to use external accounting service to help their accounting function. This research also tests the influence of asset specific factors, environment uncertainty, behavior uncertainty, trust in accounting, technical competence, and competition level on SMEs' decision to use outsourced accounting service. Furthermore, this research also serves as a development of the research conducted by Kamyabi \& Devi (2011d), i.e. in addition to testing the influence of those factors above on the use of outsourced accounting service, it also investigates the impact of this outsourcing service use on SMEs' performance ((Hafeez, 2013; Kamyabi \& Devi, 2011b). Secondly, what makes this research different from the previous one is that it is conducted in a different place, i.e. Indonesia, and thus it is possible that the criteria of SMEs to be included as its sample are different since each country has their own varied definitions of SMEs.

This research aims at explaining the factors which affect SMEs' decision to use outsourced accounting service and the impact of such use of outsourced accounting service on its performance by applying a combined TCE and RBV theories. In TCE perspective, it is believed that a company will try to keep their transaction and production costs in balance through their decisions to use internal or external resources in performing a function (Kamyabi \& Devi, 2011d). Furthermore, RBV theory suggests that 
when a company has no valuable, unique, inimitable and organized resources and capability, it ought to use outsourcing to deal with these weaknesses (McIvor, 2009). Moreover, RBV theory shows that it is possible SMEs to obtain access and availability of both tangible and intangible resources which will have positive impacts on its performance (Jeronimo, Lopez, \& Pinzon, 2019).

Also, it is expected that this research could give practical contributions. Firstly, this research is expected to give a new insight for SME owners and managers alike into the benefits of using outsourced accounting services in both performing the accounting function and improving company's performance. Secondly, this research result is expected to motivate Kantor Jasa Akuntansi (KJA) or accounting service office to play its role more actively to help the implementation of accounting function based on SMEs' needs. Thirdly, this research result is expected to be a reference for the government to make policies aiming at facilitating the application of accounting function within SMEs. Finally, this research result is expected to trigger more cooperations between the government and KJA to disseminate and provide accountant services in SMEs.

\section{LITERATURE REVIEW AND HYPOTHESES}

\section{SMEs (Small and Medium Enterprises)}

The definition of SMEs is different from one country to another, based on their relevant economic size, corporate sector structure, and policy framework (Haselip, Desgain, \& Mackenzie, 2014). In Indonesia, there are many definitions of SME, including the one based on the Presidential Decree of Indonesia No. 99/1998 (Indonesia, 1998), Badan Pusat Statistik (BPS) or Statistics Indonesia, and Law (2008). Based on the Presidential Decree of Indonesia No. 99/1998 (Indonesia, 1998), small enterprises are people's small-scale economic activities with a field/type of business being mostly classified as small business activities and needing protection to prevent business competition. BPS (Statistics Indonesia) defines SME based on its number of manpower, in which, according to BPS, small enterprises are business entities with 5 to 19 workers, and medium enterprises are the ones with 20 to 99 workers (Anggadwita \& Mustafid, 2014).

Under the Law of 2008, SMEs are independently-established productive economic businesses, run by persons or business entitties, with such criteria as: a) Micro business: net assets range Rp50,000,000.00 Rp500,000,000.00 excluding business premises such as land and place of business or a sum of annual sales at a maximum of Rp300,000,000.00 b) Small business: net assets range Rp50,000,000.00 Rp500,000,000.00 excluding business premises such as land and place of business or a sum of annual sales from Rp300,000,000.00 to Rp2.500.000.000,00; and c) Medium business: net assets over Rp500,000,000.00 to Rp10,000,000,000.00 excluding business premises such as land and place of business or a sum of annual sales of more than Rp2,500,000,000.00 to Rp50,000,000,000.00 (Law, 2008).

\section{Accounting Function in SMEs}

Accounting is a process of measuring, communicating, and interpreting financial activities (Jayabalan et al., 2009). In general, accounting can be classified into financial accounting and management accounting information, where the financial accounting information is intended for external reporting requirement, and the management accounting is used for the purpose of making internal management decisions (Kamyabi \& Devi, 2011b). The management accounting plays a significant potential role for SMEs (Nandan, 2010). SMEs need to obtain accurate and reliable management accounting information from their accountants (Kamyabi \& Devi, 2011d). Considerinug the importance of SMEs in every economy, and given the fact that they represent a reform and major companies can grow, it is assumed that SMEs needs timely, accurate, reliable, and readily comprehensible management accounting information (Nandan, 2010). 


\section{Concept of Outsourcing}

The concept of outsourcing was introduced for the first time around 1980s (Hafeez, 2013; Kamyabi \& Devi, 2011b). In this research, outsourcing refers to companies providing external accounting services (Everaert, Sarens, \& Rommel, 2006; Hafeez, 2013; Kamyabi \& Devi, 2011b). Furthermore, it can be seen that in accounting, outsourcing is a process which involve external accountants and pprofessional accountant firm (Everaert et al., 2006; Hafeez, 2013; Kamyabi \& Devi, 2011b).

Some studies draw a conclusion that the use of outsourcing services by SMEs in performing their accounting function is a good option. Previous research concludes that the function of outsourced accounting is an option for SMEs to maintain their competitive advantage in their business environment since outsourcing can lower the burdens borne by SMEs (Jayabalan et al., 2009). Outsourcing offers a benefit to increase flexibility, thus SMEs are protected from unstable workload (Everaert et al., 2006). A company's performance could increase directly when it involves external accountants as its advisors (Kamyabi \& Devi, 2011c). A previous study concludes, upon using a survey with 658 questionnaires, that the function of outsourced accounting in SMEs supports the TCE prediction and RBV consideration, i.e. for asset specificity, accountant confidence, competition pressure and company's strategy (Kamyabi \& Devi, 2011a).

\section{TCE (Transaction Cost Economics)}

TCE theory was introduced by Coase (Hafeez, 2013; Kamyabi \& Devi, 2011d, 2011b) in which he explains that a company's costs are used to provide an internal activity known as production costs, meanwhile the cost to purchase this activity is called transaction cost (Thouin, Hoffman, \& Ford, 2009). TCE is believed effective in increasing the company's understanding, whether they need to use outsourcing services or not (Tazilah et al., 2019). Marshall, McIvor and Lamming (2007) suggest that transaction cost consists of direct and indirect costs from negotiation, monitoring, explicit execution, and implicit contracts between companies and service providers (Kamyabi \& Devi, 2011d).

In TCE perspective, basically a company strives to keep their transaction and production costs in balance by making decisions on whether or not it should use internal or external resources in performing its functions (Dibbern \& Heinzl, 2009; Kamyabi \& Devi, 2011d). The approach identifies the envrionmental and human factors related to how companies can reduce the costs for their transactions (Agburu et al., 2017). Meanwhile, the key factors which influence transaction cost of accounting function outsourcing include asset specification, environment uncertainty, behavior uncertainty (Dibbern \& Heinzl, 2009; Everaert et al., 2006; Hafeez, 2013; Kamyabi \& Devi, 2011d), and trust in accountants (Everaert et al., 2006; Hafeez, 2013; Kamyabi \& Devi, 2011d, 2011a, 2011b).

\section{RBV (Resource Based View)}

RBV or resource-based theory came from penrose, 1959 (Hafeez, 2013; Kamyabi \& Devi, 2011d, 2011b). RBV could defined as the complete ability of assets, organizational process, resources, company atttibute information, and knowledge collected by the company to design and apply strategies (Hafeez, 2013). Barney (1991) classifies resources into three, namely physical, human dan organizational resources (Hafeez, 2013). RBV has been used by companies to make outsourcing decisions, where it turns transaction and opportunity costs into competitive advantage (Kamyabi \& Devi, 2011d, 2011b). RBV also allows SMEs to obtain access to and availability of resources, be it tangible or intangible, which will have positive impact on performance (Jeronimo et al., 2019).

Basically, the main principle of RBV is that companies have a set of unique assets and resources, in which if they are capable of utilizing them, then they will obtain competitive advantage (Tazilah et al., 2019). Moreover, RBV serves as a framework which is helpful for outsourced accounting function when SMEs have to deal with competitive pressure (Kamyabi \& Devi, 2011a). Finally, RBV explains that technical competence (Hafeez, 2013; Kamyabi \& Devi, 2011d, 2011c) and competition level (Hafeez, 2013; Kamyabi \& Devi, 2011d) are the vital factors which influence a company's decision to use outsourcing in performing its accounting function. 


\section{Asset specification on Company's Decision to Use Outsourced Accounting Service}

There are two general types of asset specification, namely physical assets (land, equipment, machinery, and so on) and human assets (expertise, ability, knowledge, and so forth). A high asset specification shows that the costs invested in physical facilities, human capital, and specific knowledge (Zhang, Ma, \& Qu, 2018). Based on the previous literature, it is said that asset specification is one of important factors which determine the motivation to use outsourcing in TCE perspective (Altin, Uysal, \& Schwartz, 2018; Reza et al., 2017). Previous studies also suggest that asset specification is the most important controller in outsourcing, such as financial accounting function, internal audit, and information technology (Kamyabi \& Devi, 2011a, 2011b, 2011d). Previous studies also find that asset specification has a negative correlation with outsourcing (Altin et al., 2018), where the higher the asset specification level of accounting activity the lower the intensity of accounting outsourcing activity (Hafeez, 2013; Kamyabi \& Devi, 2011b). A previous study also finds that asset specification is a significant determinant in the decision to use outsourcing (Everaert et al., 2006).

$\mathrm{H}_{1}$ : Asset specification has a negative significant influence on a company's decision to use outsourced accounting service.

\section{Environment Uncertainty on A Company's Decision to Use Outsourced Accounting Service}

Environment uncertainty is another significant factor which influence the decision of outsourcing in SMEs (Hafeez, 2013). Examples of the uncertainties in this case include the difficulty in predicting future and technology development and inability to correctly evaluate the needed competences and activities (Altin et al., 2018). This is supported by a previous study which suggests that the scope of uncertainty such as uncertain demands and technology development (Reza et al., 2017). TCE assets that if a company can predict and manage the workload related to the right management accounting practices, then the transaction cost should be low and the company will outsource their accounting activity (Ellram, Tate, \& Billington, 2008; Everaert et al., 2006). On the contrary, high uncertainty will create highly pricey costs to enter into a contract with an external accounting firm (Everaert et al., 2006). Therefore, high environment uncertainty makes outsourcing less interesting than insourcing (Reza et al., 2017). The statement above is supported by another study which finds that environment uncertainty has a significant negative correlation with accounting outsourcing (Hafeez, 2013).

$\mathrm{H}_{2}$ : Environment uncertainty has a negative influence on a company's decision to use outsourced accounting service

\section{Behavior Uncertainty on A Company's Decision to Use Outsourced Accounting Service}

Uncertainty refers to transaction risks which may occur before and after a contract agreement (Zhang et al., 2018). A study indicates that behavior uncertainty is important in terms of performing an outsourced accounting function (Hafeez, 2013). The term behavior uncertainty can be defined as the difficulty to evaluate whether (internal or external) accountants performs their job accurately and whether they have done their best with the ability they have (Everaert et al., 2006). Under an uncertainty, one depends on several heuristic principles to simplify the complex tasks of evaluating probability and values from alternatives (Chae, Lawson, Kull, \& Choi, 2019). TCE predicts that the higher the behavior uncertainty in management accounting function the higher the transaction costs would be and the accounting function would be performed internally (Everaert et al., 2006; Kamyabi \& Devi, 2011d). Results of a previous study show that high behavior uncertainty makes a company prefer using their internal resources (Reza et al., 2017). This statement is supported by previous studies which find that behavior uncertainty has a significant negative influence on accounting outsourcing (Hafeez, 2013; Kamyabi \& Devi, 2011d).

$\mathrm{H}_{3}$ : Behavior uncertainty has a negative significant influence on a company's decision to use outsourced accounting service 


\section{Trust in Accountants on A Company's Decision to Use Outsourced Accounting Service}

Trust in this research means the trust put in the provider of outsouced accounting services, where the trust in this case requires the owner/manager to expect that the outsourced accountant service providers (1) have the expertise and ability, (2) are reliable to fulfill their legal obligations, (3) have consistent attitude, (4) and will charge a cost which matches the accounting activities they provide (Everaert et al., 2006; Kamyabi \& Devi, 2011d, 2011b). TCE theory supports the view that when there is trust, it is possible to lessen the formal control mechanism and the company is more likely to outsource their accounting function to make it run (Kamyabi \& Devi, 2011d, 2011b). A previous study also supports this, finding that when trust is present between companies, it can reduce the transaction cost since it can limit uncertainty and opportunism, reduce business risks, and be a source of competitive advantage (Blackburn et al., 2018). This statement implies that the higher the trust in outsourced accountant service provider, the more likely the SME owners/managers to prefer using outsourced accounting service to perform their accounting function. This is supported by previous studies which find that trust has a significant positive correlation with outsourced management accounting (Blackburn et al., 2018; Hafeez, 2013; Kamyabi \& Devi, 2011a, 2011b).

$\mathrm{H}_{4}$ : Trust in accountants has a significant positive influence on a company's decision to use outsourced accounting service

\section{Technical Competence on Company's Decision to Use Outsourced Accounting Service}

Studies show that technical competence, in this case the accounting competence, is one of the factors which significantly attract SMEs to outsource their accounting function (Hafeez, 2013). The competence of outsourced accounting service shows their excellence as business advisors so that a competent outsourced accountant can determine their clients needs (Blackburn et al., 2018). RBV theory suggests that technical competence has a significant influence on outsourcing decision (Kamyabi \& Devi, 2011d). RBV theory argues that a professional external accountant is good to be placed to give comperative advantage over internal accountants since they have the appropriate qualification, experience, specific skills, industrial specialization, and the latest technology resources (Kamyabi \& Devi, 2011d, 2011c). In line with RBV theory, a previous study shows that competence has an influence on the use of accounting service by SMEs (Kipsang \& Mwangi, 2017). Furthermore, previous studies indicate that technical competence has a positive correlation with management accounting outsourcing (Hafeez, 2013; Kamyabi \& Devi, 2011d, 2011c).

$\mathrm{H}_{5}$ : Technical competence has a significant positive influence on a company's decision to use outsourced accounting service

\section{Competition Level on A Company's Decision to Use Outsourced Accounting Service}

RBV theory suggests that under a competitive circumstance, companies should be able to learn how to exploit the resources available outside the business to help them become more competitive (Kamyabi \& Devi, 2011b). Thus, outsourcing service of management accounting function serves as a preferable strategy for most SMEs to survive in the increasingly competitive market (Kamyabi \& Devi, 2011d). Competition has an influence on the use of accounting service by SMEs (Kipsang \& Mwangi, 2017). This is sypported by previous studies which find that competition level has a positive influence on outsourcing intensity (Hafeez, 2013; Kamyabi \& Devi, 2011d, 2011a, 2011b, 2011c).

$\mathrm{H}_{6}$ : Competition level has a significant positive influence on a company's decision to use outsourced accounting service.

\section{Impact of the Use of Outsourced Accounting Service on SME's Performance}

RBV perspective provides a set of resources, expertise and ability to study the strength of competitive advantage, where it eventually influences performance (Hafeez, 2013). Meanwhile, the main principle of TCE is related to the influence of options in organizational management to minimize 
transaction costs, so that the company's performance increases (Hafeez, 2013; Kamyabi \& Devi, 2011b). Outsourcing will improve a company's performance for three reasons, namely (1) outsourcing have the potential of reducing the company's bureaucracy complexity; (2) outsourcing allows SMEs to meet its production needs and mechanism to manage their economic scales with service provider specialists beyond the company, risk transfer, and lower uncertainty; and (3) when outsourcing is more efficient, SMEs are more likely to integrate and use its specific resources and capacity (Kamyabi \& Devi, 2011b). Kamyabi \& Devi (2011c) study the correlation between the use of consultation service and SMEs' performance and find that a company's performance may increase directly as long it makes a contract with external accountant as its consultant. Previous studies also conclude that outsourced accounting has a significant positive correlation with a company's performance (Ganesan et al., 2018; Hafeez, 2013; Mwangi et al., 2018).

$\mathrm{H}_{7}$ : A company's decision to use outsourced accounting service has a positive influence on SMEs' performance

Based on this hypothesis development, the conceptual framework in this research is as follows:

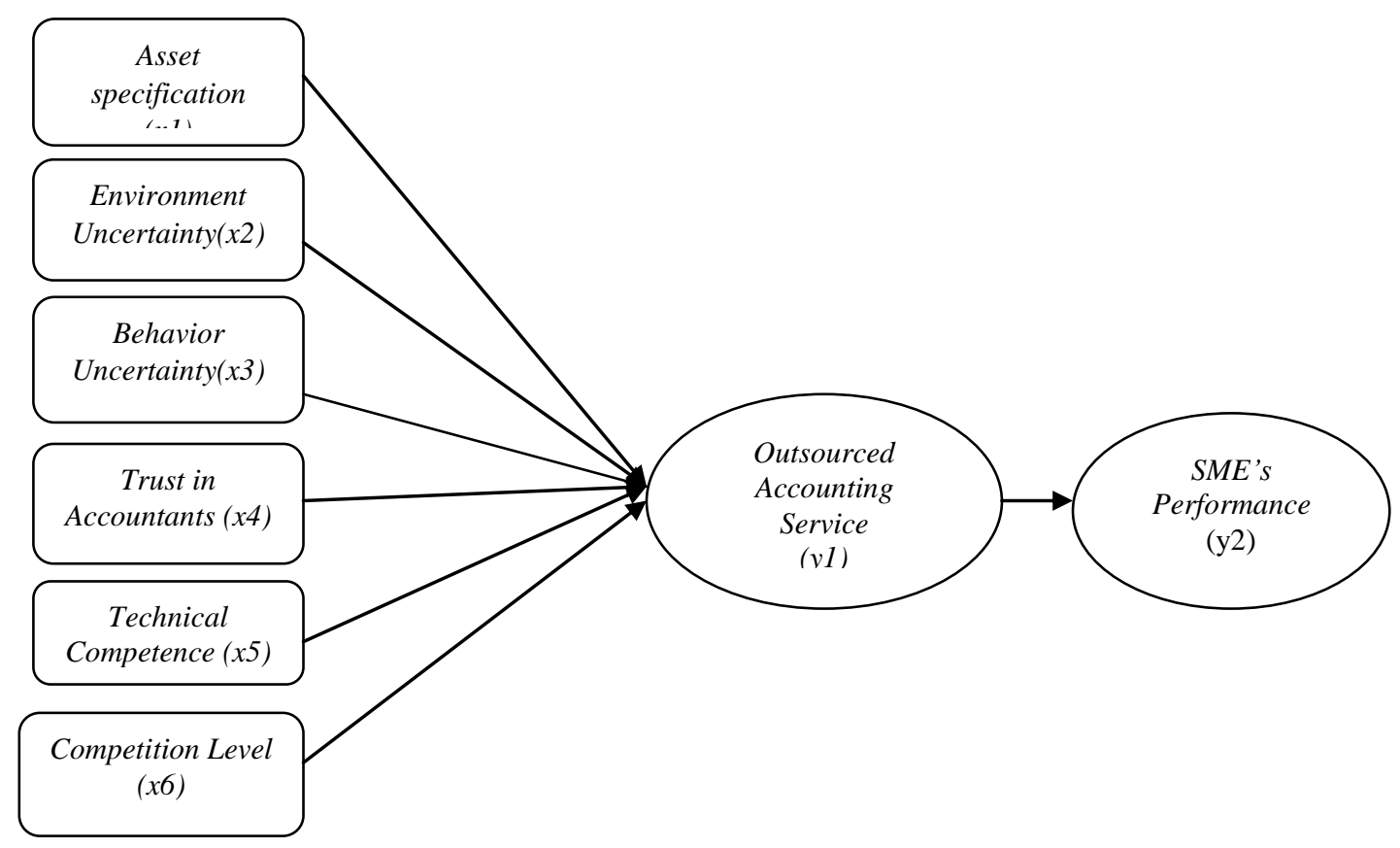

Figure 1. Conceptual Framework

\section{METHODS}

Since there are some hypotheses the researchers have formulated and want to test, this research can therefore be classified as explanatory research. The population used in this research is manufacturing SMEs located in Malang Municipality. These SMEs from manufacturing sectors were chosen since, in the researchers' opinion, the application of management accounting in a manufacturing company is more complicated and difficult than both services and trading companies. The exact number of manufacturing SMEs in Malang Municipality is unknown since the data on the number of SMEs in Malang Municipality was obtained as a whole, rather than classified based on their sector. The sample was taken using purposive sampling method, i.e. a sampling technique which is adjusted to the research objective and done using certain considerations (Sekaran and Bougie, 2010: 276-277). The criteria for sampling in this research 
were based on the definition of SMEs in Indonesia based on Statistics Indonesia (BPS) and the businesses which match the criteria under the applicable regulations, i.e. Law No. 20 Year 2008. 270 respondents were needed, in which the number of indicators was multiplied by 5 (Hair, Jr, 2015).

The data used in this research were the primary ones. The term primary data mean the answers from the respondents, in which these respondents were owners/managers/employees working for the SMEs located in Malang Municipality. The data in this research were collected using a survey. The survey was carried out by distributing questionnaire to the respondents who were also the research sample. The questionnaire was adapted from previous studies (Hafeez, 2013; Kamyabi \& Devi, 2011d, 2011b), consisting of 54 question instruments (appendix 1). The researchers opted to personally bring the questionnaire to the research location to the improve the respond rate.

This research have eight latent variables or constructs. The endogenous variables in this research were SMEs' performance and outsourced accounting service. The term SMEs' performance had the same meaning as the research conducted by Hafeez (2013), in which he classified company's performance into three categories, namely (1) financial performance, (2) non-financial performance, and (3) company's performance after using outsourced accounting service. Financial performance is shown by such indicators as profitability, sales growth, return on asset, and cash flow, and non-financial performance will be shown by lifestyle, independence, and job security. Outsourced accounting service played the role of a mediating or interverning variable. The term outsourced accounting service provider here means a company providing consultation services from their external or professional accountants which cooperate with SMEs to perform these SMEs' management accounting function.

Furthermore, there were six exogenous variables, namely asset specification, environment uncertainty, behavior uncertainty, trust in accountants, technical competence, and competition level. The term asset specification here means the characteristics of assets owned by a company as a requirement to use outsourced accounting service, be it physical or human assets. Environment uncertainty means unstability and unpredictable changes in relation with the accounting workload as a result of business process changes (Hafeez, 2013), and the term behavior uncertainty means the difficulty to measure accountant's performance in terms of their workloads based on the obligations assigned in SMEs (Hafeez, 2013). The term trust in accountants here means the trust that SMEs put in the provider of outsourced accountant services (Kamyabi \& Devi, 2011b, 2011d). Technical competence here is defined as external accountants which have better specific skills, competence, market knowledge, qualification, and industry experience than the internal accountant (Hafeez, 2013). Finally, competition level here means the competition faced by SME actors in their business environment.

The constructs in this research were measured using 7-point Likert scale, where 1 was the lowest and 7 was the highest scores (appendix 1). The data in this research were analyzed using Path Analysis with SEM. The data collected from the questionnaire were saved in Excel format for processing and analysis using AMOS software.

\section{RESULTS}

\section{Respondent Profile}

The questionnaire were distributed personally to the respondents' places. The questionnaire was distributed in two occassions. Firstly, the researchers personally visited the respondents' places of business, where the researchers provided some instructions and directives until the respondents finished completing the research questionnaire. Secondly, the researchers came to the meetings organized by SME community in Malang and distributed the questionnaire there. The questionnaire respond rate was $91.5 \%$, where out of 270 distributed questionnaires, 247 questionnaires were returned to the researchers. From these 247 questionnaires, $222(90 \%)$ were processable, and the remaining $25(10 \%)$ questionnaires could not be processed. The number of samples had met the SEM analysis requirements, where it was effective when it ranged from 150 to 400 samples (Haryono, 2017). The data on respondent profile in this research were 
classified based on age, education level, position in SMEs, number of workers, and sales revenue in one year. The detail of this respondent profile can be seen in the following table.

Table 1. Respondent Profile

\begin{tabular}{|lcc|}
\hline \multicolumn{1}{c}{ Respondent Classification } & Number & Percentage \\
\hline Sex: & & \\
Male & 88 & $39.64 \%$ \\
Female & 134 & $60.36 \%$ \\
Total & $\mathbf{2 2 2}$ & $\mathbf{1 0 0 \%}$ \\
\hline Education level: & 5 & $2.25 \%$ \\
\hline Elementary & 19 & $8.56 \%$ \\
\hline Junior High & 86 & $38.74 \%$ \\
\hline Senior High & 36 & $16.22 \%$ \\
\hline Diploma & 70 & $31.53 \%$ \\
\hline Undergraduate & 6 & $2.7 \%$ \\
\hline Graduate & $\mathbf{2 2 2}$ & $\mathbf{1 0 0 \%}$ \\
\hline Total & & \\
Position in SME: & $\mathbf{1 9 0}$ & $\mathbf{8 5 . 5 9 \%}$ \\
\hline Owner & $\mathbf{8}$ & $\mathbf{3 . 6 0 \%}$ \\
Manager & $\mathbf{2 4}$ & $\mathbf{1 0 . 8 1 \%}$ \\
\hline Employees & $\mathbf{2 2 2}$ & $\mathbf{1 0 0 \%}$ \\
\hline Total & & \\
\hline
\end{tabular}

From 222 collected research data, it could be seen that most respondents were female SME actors (60.36\%), and only 39.64\% were male SME actors. Moreover, most respondents graduated from senior high schools at $38.74 \%$, and were followed by undergraduate education level (31.53\%). Most respondents were the SME owners themselves, hence they should have owned a sound understanding of their management accounting function as per their business needs.

Furthermore, the level of use of outsourcing for management accounting function by respondents could be seen from their answers in outsourced accounting service construct. This construct was measured using 7-point Likert scale (appendix 1). The results of respondents' answers in this construct could be seen in table 2.

Table 2. Use of Outsourced Accounting Service by Respondents (in percentage)

\begin{tabular}{|c|c|c|c|c|c|c|c|}
\hline Function & \multicolumn{7}{|c|}{ Likert Scale } \\
\hline Accounting & 1 & 2 & 3 & 4 & 5 & 6 & 7 \\
\hline Bookkeeping & 82.4 & 1.8 & 2.7 & 1.4 & 3.2 & 5.4 & 3.2 \\
\hline Financial statement preparation & 81.1 & 2.7 & 2.3 & 2.3 & 2.7 & 5.4 & 3.6 \\
\hline Payroll & 80.6 & 2.7 & 3.6 & 2.3 & 5.0 & 4.5 & 1.3 \\
\hline Company Budget & 80.6 & 2.3 & 2.7 & 1.4 & 3.6 & 6.8 & 2.7 \\
\hline Customer Profit Analysis & 82.0 & 1.4 & 2.3 & 3.2 & 2.7 & 6.3 & 2.3 \\
\hline Product Costs & 80.6 & 2.7 & 0.9 & 4.1 & 3.2 & 6.8 & 1.8 \\
\hline Financial Planning & 80.6 & 1.8 & 2.7 & 2.7 & 1.4 & 7.7 & 3.2 \\
\hline Financial Management & 81.1 & 1.4 & 4.1 & 2.3 & 1.4 & 7.7 & 2.3 \\
\hline Design/ Review of SPI & 79.7 & 2.7 & 3.6 & 2.3 & 1.8 & 8.6 & 1.4 \\
\hline
\end{tabular}

Based on the table above, it could be seen that most actors of SMEs in Malang Municipality opted to use outsourcing in performing all of their management accounting functions. This was shown by fact that most respondents' answers were placed on Likert scale 1, where this Likert scale 1 showed that the SMEs in manufacturing sector in Malang Municipality did not use outsourced accounting service at all. Meanwhile, those using outsourced accounting service ranged only from 5.4\% to $8.6 \%$ for each accounting function. This showed that most actors of manufacturing sector SMEs in Malang Municipality lacked 
awareness of utilizing outsourced accounting service to perform the management accounting function in their businesses.

\section{Validity and reliability tests}

Every indicator which had met the validity assumption was convergent if CR $>2 \mathrm{x}$ S.E and if its probability value $>0.05$ then it could be said as valid (Waluyo, 2016). Upon validity test, indicators Y2.1, Y2.2, Y2.4, Y2.5, and Y2.7 were found invalid (appendix 2), hence these indicators were excluded. Meanwhile, the other indicators were declared as valid, thus they could be used to measure the research variables. Furthermore, the researchers carried out the reliability test. The reliability was tested using construct reablity (CR) test, where it showed the reliability and consistency of the data. A variable was said to be reliable if it had CR value $>0.7$ (Waluyo, 2016). Furthermore, reliability was also measured based on AVE value, in which the criterion was for the variable to have AVE value $>0.5$ to be reliable. After excluding the invalid indicators of SMEs' performance, the calculation results (see appendix 3) showed that all research variables could be said as reliable.

\section{Model Goodness of Fit Test}

The model goodness of fit was evaluated using criteria goodness of fit indices. The model criteria and its critical values which had data goodness of fit were presented in the following table.

Table 3. Result of Model Goodness of Fit Test

\begin{tabular}{lccc}
\hline Goodness of fit indices & Cut of value* & Analysis Result** & $\begin{array}{c}\text { Model } \\
\text { Evaluation }\end{array}$ \\
\hline Chi Square & Expected to be small & 585.10 & Good \\
Probablity & $\geq 0.05$ & 0.279 & Good \\
CMIN/DF & $\leq 2.00$ & 1.278 & Good \\
RMSEA & $\leq 0.08$ & 0.035 & Good \\
GFI & $\geq 0.90$ & 0.952 & Good \\
AGFI & $\geq 0.90$ & 0.919 & Good \\
TLI & $\geq 0.95$ & 0.960 & Good \\
CFI & $\geq 0.95$ & 0.924 & Good \\
\hline
\end{tabular}

Based on the table above, it could be seen that all indices met the criteria of goodness of fit indices, hence it was safe to say that the model fulfilled the goodness of fit with the data above.

\section{Hypothesis Testing}

The hypotheses in this research aimed at discovering the influence of asset specification, environment uncertainty, behavior uncertainty, trust in accountants, technical competence, and competition level on the use of outsourced accounting service in SMEs. Furthermore, they also aimed at finding out the impact of such use of outsourced accounting service on SMEs' performance. To test these hypotheses in this research, SEM analysis with AMOS software was used. A hypothesis would be accepted if the values of $\mathrm{CR}>1.96$ and $p<0.05$ and it would be rejected if the values of $\mathrm{CR}<1.96$ and $\mathrm{p}>0.05$. Meanwhile, the result of hypothesis testing calculation was as follows.

Table 4. Result of Hypothesis Testing

\begin{tabular}{|c|c|c|c|c|c|c|c|}
\hline \multicolumn{3}{|c|}{ Variable } & Estimate & S.E. & C.R. & $\mathbf{P}$ & Label \\
\hline Y1 & $<--$ & $\mathrm{X} 1$ & -.364 & .185 & -1.971 & .049 & Negative, Significant \\
\hline Y1 & $<---$ & $\mathrm{X} 2$ & .559 & 286 & 1.956 & .050 & Positive, Significant \\
\hline Y1 & $<---$ & $\mathrm{X} 3$ & .240 & 215 & 1.115 & .265 & Positive, Insignificant \\
\hline Y1 & $<--$ & $\mathrm{X} 4$ & -.060 & 188 & -.320 & .749 & Negative, Insignificant \\
\hline Y1 & $<---$ & $\mathrm{X} 5$ & .476 & .156 & 3.053 & .002 & Positive, Significant \\
\hline Y1 & $<---$ & X6 & -.648 & .254 & -2.548 & .011 & Negative, Significant \\
\hline Y2 & $<--$ & Y1 & 1.072 & .065 & 16.601 & $* * *$ & Positive, Significant \\
\hline
\end{tabular}


Based on the table above, the calculation of X1 on Y1 showed that the values of CR (1.971) > 1.96 and $\mathrm{p}(0.049)<0.05$. In addition, the estimate value $(-0.364)$ indicated that the influence tended to be negative one, hence hypothesis 1 was accepted. The calculation of influence of X2 on Y2 showed values of $\mathrm{CR}(1,956)<1.96 ; \mathrm{p}(0.05)$; and estimate value 0.559 , meaning that it had a positive and significant value. This meant the second hypothesis was rejected.

The behavior uncertainty variable showed insignificant value, where $\mathrm{p}(0.265)>0.05$ and CR value $(1.115)<1.96$; and the estimate value showed a positive direction $(0.240)$, thus the third hypothesis was rejected. Likewise, the trust in accountants variable had insignificant value as shown by p value (0.749) > 0.05 and $\mathrm{CR}$ value $(-0.320)<1.96$. Meanwhile, the estimate value showed a negative estimate direction $(-$ $0.060)$, therefore the fourth hypothesis was rejected.

The calculation in table 4 above showed that the technical competence variable had values of CR $(3.053)>1.96$ and $p(0.002)<0.05$. Additionally, the estimate value also indicated a positive value. Based on this calculation, it could be said that the fifth hypothesis was accepted. Also, based the calculation in table 4 it was found that the competition level variable had values of CR $(2.548)>1.96$ and $\mathrm{p}(0.011)<$ 0.05; yet its estimate value showed a negative direction (-0.648), thus the sixth hypothesis was rejected. Moreover, the hypothesis test was also carried out to figure out the effect of use of outsourced accounting service (intervening variable) on SMEs' performance. Based on the calculation in table 4 above, it could be seen that the values of CR $(16.601)>1.96$; $p(0.000)<0.05$; and its estimate value was positive (1.072), meaning that the seventh hypothesis was accepted.

\section{DISCUSSION}

\section{Asset Specification on A Company's Decision to Use Outsourced Accounting Service}

Based on the hypothesis testing above, the first hypothesis was accepted, where the asset specification had a negative significant influence on a company's decision to use outsourced accounting service. This finding was consistent with the research conducted by Everaert et al. (2006), Hafeez (2013), and Kamyabi \& Devi (2011b, 2011d, 2011a). This meant that the higher the asset specification owned by SMEs, the more likely for SME actors in Malang Municipality to decide to not use outsourced accounting service. Furthermore, this finding was also consistent with TCE theory which suggested that due to the high asset specification, SMEs preferred performing their accounting activities internally to outsourcing their accounting activities (Everaert et al., 2006). TCE model showed that when the management accounting function contained high asset specification, the search for a professional accountant would take longer time and harder contract negotiation (Kamyabi \& Devi, 2011b).

\section{Environment Uncertainty on A Company's Decision to Use Outsourced Accounting Service}

The research result indicated that the second hypothesis was rejected. This research did not support TCE theory which stated that the higher the environment uncertainty level, the more pricey the outsourced accounting service costs would be, leading SMEs to preferred not using outsourced accounting service. This research result showed that the environment uncertainty variable had a significant positive influence on a company's decision to use outsourced accounting service.

This research result supported the research conducted by Altin et al. (2018), Everaert et al. (2006), and Kamyabi \& Devi (2011d). This showed that when SMEs were less capable of predicting their accounting function, then it was more likely for these SMEs to opt for intensely using outsourced accounting service (Everaert et al., 2006). This was because using outsourced accounting service could help SMEs minimize the business risks they had to face, such as having no adequate internal accountant resources when demands were high and on the other hand when demands were low, this internal accountant tended to had nothing to do. Outsourcing their accounting function to an accounting service provider who had expertise in their field, talent and superior resourcers helped SMEs to get more prepared in the face of environment uncertainty in their business environment. 


\section{Behavior Uncertainty on A Company's Decision to Use Outsourced Accounting Service}

The hypothesis testing above showed that the behavior uncertainty variable had a positive insignificant on SMEs' decision to use outsourced accounting service. Hence, the third hypothesis was rejected. This research finding supported the research previously conducted by Everaert et al. (2006), where behavior uncertainty was not a significant driver of SMEs' decision to use outsourced accounting service. This research finding contradicted the TCE theory and the studies carried out by Hafeez (2013) and Kamyabi \& Devi (2011d). In the researchers' humble opinion, this difference in this research result might be due to the different characteristics of SMEs in Malang Municipality and those in the place of previous studies. One of them was the fact that not all SME actors in Malang Municipality could apply well the applicable regulations. This made SME actors have to face high behavior uncertainty situation and therefore the decision to use outsourced accounting service was the right one, even if its influence was insignificant.

\section{Trust in Accountants on A Company's Decision to Use Outsourced Accounting Service}

Based on the calculation of hypothesis testing above, the fourth hypothesis was rejected, in which the trust in accountants did not serve as a significant driver to use outsourced accounting service. The research result showed that trust in accountants had a negative, yet insignificant influence on SMEs' decision to use outsourced accounting service. This research result did not support some previous studies (Kamyabi \& Devi, 2011d, 2011b), yet it supported another previous study (Everaert et al., 2006). This research finding contradicted the view of TCE theory which suggested that when there was trust, companies were more likely to outsource their accounting function (Kamyabi \& Devi, 2011d, 2011b).

From this finding, it could be seen that trust was not a main factor for SMEs in deciding to whether use outsourced accounting service or not. It was possible that this different research result was due to the different characteristics of SME actors in Malang Municipality and those in the previous study locations, where SME actors lacked care and awareness to apply the accounting function in running their businesses. Andriani et al, (2014) suggest that it is more important for SMEs to earn more profits without having to implement accounting (Cahyaningtyas, 2017). This lack of care might be because SME actors thought they had not met the legal requirements to apply the accounting function. This was supported by Kipsang \& Mwangi's (2017) study who found that $86 \%$ of SME actors in Kenya disagreed with the statement that SME actors had met the legal requirements to prepare the appropriate bookkeeping. Meanwhile, a previous study found that the trust between external accountants and a company came from the development of an existing relationship (Blackburn et al., 2018).

\section{Technical Competence on A Company's Decision to Use Outsourced Accounting Service}

Judging from the hypothesis testing above, it was clear that the fifth hypothesis was accepted, where it said that technical competence gave a positive siginificant influence on SMEs' decision to use outsourced accounting service. This research result was consisted with what Blackburn et al. (2018), Hafeez (2013), and Kamyabi \& Devi (2011d, 2011c) found. One of the top factors which influenced SMEs to use external accountants was the technical competence superiority (Ganesan et al., 2018). The previous study in Kenya also noted that many respondents indicated that qualification in accounting practice influenced the decision to use outsourced accounting service (Mwangi et al., 2018)

This research finding was also consistent with RBV theory which argued that professional external accountants were good to be placed to give comparative advantage for the appropriate qualification, experience, specific skills, industry specialization, and latest technology resources they had (Kamyabi \& Devi, 2011d, 2011c; Nandan, 2010). Accountants and SME actors believed that the competence of external accountants included various business advices, such SME actors' compliance with the applicable regulations and so on (Blackburn et al., 2018). Based on the explanation above, it could be seen that technical competence was an important factor which affected the decision to use outsourced accounting service by SME actors (Hafeez, 2013). 


\section{Competition Level on A Company's Decision to Use Outsourced Accounting Service}

Furthermore, the sixth hypothesis was rejected, where the hypothesis testing result showed that competition level had a negative significant influence on the use of outsourced accounting service by SMEs. This research finding contradicted RBV theory, in which this theory argued that under a competitive circumstance, companies should be capable of learning how to exploid the resources available beyond their business to help make them more competitive (Kamyabi \& Devi, 2011b). This research result did not support the previous studies (Hafeez, 2013; Kamyabi \& Devi, 2011d, 2011b, 2011c). In the researchers' opinion, there were some causes to this, including the facts that: (1) the research was conducted in a different location and scope. The previous studies were conducted to cover countries, namely Iran and Pakistan, and this research was conducted to cover much smaller location, namely Malang Municipality; (2) SME actors in Malang Municipality lacked the awareness of how important it was to implement management accounting practices in running their business, hence when these SME actors had to face a high competition level, they focused more on its product innovation or marketing activities.

\section{Impact of Use of Outsourced Accounting Service on SMEs' Performance}

Considering the fact that the seventh hypothesis was accepted, this research supported the findings of previous studies (Ganesan et al., 2018; Hafeez, 2013; Kamyabi \& Devi, 2011b, 2011c; Kotabe \& Mol, 2009; Mwangi et al., 2018). Based on this research result, it could be seen that the decision to use outsourced accounting service was an important factor in improving SMEs' performance. Previous research also suggested that external accountant (non-audit service) became their first choice for SME actors to improve their business performance and maintain their business in a long run (Ganesan et al., 2018).

This was because using outsourced accounting service could minimize risks, lowered bureaucracy complexity, reduced overhead costs and uncertainty; allowed SMEs to achieve an economic scale in their business production and operation as a whole, which in turn improved SMEs' performance (Hafeez, 2013). Even more than this, Back (1978, 1981 and 1985) found that minor companies which used accountant service could minimize the possibility of liquidation, failure, business stagnation, and lacking access to credits than those which did not use any accounting service (Kipsang \& Mwangi, 2017).

\section{CONCLUSION}

Results of this research indicated that asset specification, environment uncertainty, technical competence, and competition level were important factors which influenced SMEs' decision to use outsourced accounting service. Meanwhile, behavior uncertainty and trust in accountant had some influence, yet it was insignificant on SMEs' decision to use outsourced accounting service. In addition, this research's findings showed that the use of outsourced accounting service influenced SMEs' performance, where SMEs' performance could increase when SMEs decided to use outsourced accounting service. The recommendations for further research include: (1) to expand the research area, not limited only to Malang Municipality; (2) to involve SMEs in other sectors, and (3) to use perspectives other than TCE and RBV.

\section{REFERENCES}

Agburu, J. I., Anza, N. C., \& Iyortsuun, A. S. (2017). Effect of outsourcing strategies on the performance of small and medium scale enterprises (SMEs). Journal of Global Entrepreneurship Research, 7(1), 1-34. https://doi.org/10.1186/s40497-017-0084-0

Altin, M., Uysal, M., \& Schwartz, Z. (2018). Revenue Management Outsourcing: A Hybrid Model of Transaction Cost Economics and Organizational Capability. Cornell Hospitality Quarterly, 59(2), 112-124. https://doi.org/10.1177/1938965517730318 
Anggadwita, G., \& Mustafid, Q. Y. (2014). Identification of Factors Influencing the Performance of Small Medium Enterprises (SMEs). Procedia - Social and Behavioral Sciences, 115, 415-423. https://doi.org/10.1016/j.sbspro.2014.02.448

Blackburn, R., Carey, P., \& Tanewski, G. (2018). Business advice by accountants to SMEs: relationships and trust. Qualitative Research in Accounting and Management, 15(3), 358-384. https://doi.org/10.1108/QRAM-04-2017-0022

Cahyaningtyas, F. (2017). Duality in Small and Medium Enterprise Accounting Practices. Journal of Innovation in Business and Economics, 1(02), 59. https://doi.org/10.22219/jibe.vol1.no02.11-22

Carey, P. J. (2015). External accountants' business advice and SME performance. Pacific Accounting Review, 27(2), 166-188. https://doi.org/10.1108/PAR-04-2013-0020

Chae, S., Lawson, B., Kull, T. J., \& Choi, T. (2019). To insource or outsource the sourcing? A behavioral investigation of the multi-tier sourcing decision. International Journal of Operations and Production Management, 39(3), 385-405. https://doi.org/10.1108/IJOPM-04-2018-0231

Cullinan, C. P., \& Zheng, X. (2017). Accounting outsourcing and audit lag. Managerial Auditing Journal, 32(3), 276-294. https://doi.org/10.1108/MAJ-03-2016-1349

Dibbern, J., \& Heinzl, A. (2009). Outsourcing of Information Systems Functions in Small and Medium Sized Enterprises: A Test of a Multi-Theoretical Model. Business \& Information Systems Engineering, 1(1), 101-110. https://doi.org/10.1007/s12599-008-0008-1

Ellram, L. M., Tate, W. L., \& Billington, C. (2008). Offshore outsourcing of professional services: A transaction cost economics perspective. Journal of Operations Management, 26(2), 148-163. https://doi.org/10.1016/j.jom.2007.02.008

Everaert, P., Sarens, G., \& Rommel, J. (2006). Outsourcing of Accounting Tasks in SMEs : a An extended TCE Model lish s E in nom PAPER co Vol Is Is (D/2006/7012/54).

Ganesan, Y., Haron, H., Amran, A., \& Pitchay, A. A. (2018). It is the External Accountant Matter in Business Performance of Small and Medium Enterprises? The Role of Non-Audit Services. International Academic Journal of Accounting and Financial Management, 5(4), 36-48. Retrieved from www.iaiest.com

Hafeez, A. (2013). An Empirical Investigation Of Factors Influencing Management Accounting Outsourcing Practics Among Smes In Pakistan And The Effect Of Outsourcing On Firm's Performance. University of Agder. https://doi.org/10.1016/0011-2275(85)90175-4

Hair, Jr, J. F. (2015). Essentials of Business Research Methods. Essentials of Business Research Methods. https://doi.org/10.4324/9781315704562

Haryono, S. (2017). METODE SEM Untuk Penelitian Manajemen AMOS LISREL PLS (1st ed., p. 1 s/d 62). PT. Luxima Metro Medika.

Haselip, J., Desgain, D., \& Mackenzie, G. (2014). Financing energy SMEs in ghana and senegal: Outcomes, barriers and prospects. Energy Policy, 65, 369-376. https://doi.org/10.1016/j.enpol.2013.10.013

Hidayati, U. (2013). Kebutuhan Konsultan Keuangan dan Perpajakan Bagi SME DI KOTA SEMARANG. JURNAL RISET ACCOUNTING TERAPAN, 1(2), 129-138.

Husin, M. A., \& Ibrahim, M. D. et al. (2014). The Role of Accounting Services and Impact on Small Medium Enterprises (SMEs) Performance in Manufacturing Sector from East Coast Region of Malaysia: A Conceptual Paper. Procedia - Social and Behavioral Sciences, 115(Iicies 2013), 5467. https://doi.org/10.1016/j.sbspro.2014.02.415 
Indonesia, R. Keputusan Presiden RI no. 99 tahun 1998 tentang: Usaha Mikro, Kecil dan Menengah., Jakarta $§(1998)$. Retrieved from file:///H:/BSI_2018/PENELITIAN_BSI2018/Pajak Penghasilan Final_UMKM/KEPPRES_1998_99.pdf\%0D

Jayabalan, J., Dorasamy, M., Ramlan, M., \& Ching, N. K. . (2009). Outsourcing of Accounting Functions amongst SME Companies in Malaysia: An Exploratory Study. Accountancy Business and the Public Interest, 8(2), 96-114. https://doi.org/10.1.1.506.8182

Jeronimo, J. M. ., Lopez, R. . F., \& Pinzon, P. A. (2019). Resource-Based View and SMEs Performance Exporting through Foreign Intermediaries: The Mediating $\mathrm{E}$ ff ect of Management Controls. Sustainability, 1-26. Retrieved from https://www.mdpi.com/2071-1050/11/12/3241

Kamyabi, Y., \& Devi, S. (2011a). An Empirical Investigation of Accounting Outsourcing in Iranian SMEs: Transaction Cost Economics and Resource-Based Views. International Journal of Business and Management, 6(3), 81-94. https://doi.org/10.5539/ijbm.v6n3p81

Kamyabi, Y., \& Devi, S. (2011b). The impact of accounting outsourcing on Iranian SME performance: Transaction cost economics and resource-based perspectives. World Applied Sciences Journal, 15(2), 244-252. https://doi.org/10.1.1.389.7407

Kamyabi, Y., \& Devi, S. (2011c). Use of Professional Accountants' Advisory Services and its Impact on SME Performance in an Emerging Economy: A Resource-based View. Journal of Management and Sustainability, 1(1), 43-55. https://doi.org/10.5539/jms.v1n1p43

Kamyabi, Y., \& Devi, S. (2011d). Using Transaction Cost Economics and Resource-Based Views in Management Accounting Outsourcing : An Empirical Study of Iranian SMEs. Middle-East Journal of Scientific Research, 10(1), 87-98.

Kemenkop. (2017). Perkembangan Data Usaha Mikro, Kecil, dan Menengah (UMKM) 2016-2017. Retrieved from http://www.depkop.go.id/berita-information/data-information/dataumkm/?eID=tx_rtgfiles_download\&tx_rtgfiles_pi $1 \% 5$ Buid $\% 5 \mathrm{D}=9$

Kipsang, B. S., \& Mwangi, M. (2017). Factors influencing the use of accounting services by small and medium enterprises in Kenya. Journal of Accounting, 1(1), 44-59.

Kotabe, M., \& Mol, M. J. (2009). Outsourcing and financial performance: A negative curvilinear effect. Journal of Purchasing and Supply Management, 15(4), 205-213. https://doi.org/10.1016/J.PURSUP.2009.04.001

McIvor, R. (2009). How the transaction cost and resource-based theories of the firm inform outsourcing evaluation. Journal of Operations Management, 27(1), 45-63. https://doi.org/10.1016/j.jom.2008.03.004

Mwangi, G. M., Mutiso, A., \& Mungai, D. (2018). Assessing the Influence of Accounting Outsourcing on Financial Performance of Small and Medium Enterprises in Thika Subcounty, Kenya. Management and Economics Research Journal, 04, 148. https://doi.org/10.18639/merj.2018.04.655595

Nandan, R. (2010). Management Accounting Needs of SMEs and the Role of Professional Accountants. A Renewed Research Agenda. JAMAR, 8(1), 65-77.

Reza, M., Leila, J., Vosta, N., Reza, M., Leila, J., Vosta, N., ... Management, P. (2017). Sport , Business and Management: An International Journal Article information:

Rodriguez, T. F. E., \& Fierro, J. C. R. (2016). Factors determining hotel activity outsourcing. An approach based on competitive advantage. International Journal of Contemporary Hospitality Management. https://doi.org/https://doi.org/10.1108/IJCHM-05-2016-0291

Tazilah, M. D. A. K., Majid, M., \& Suffari, N. F. (2019). Effects of Outsourcing Internal Audit Functions Among Small \& Medium Enterprises. International Journal of Business and Technology 
Management, 1(1), 28-34. Retrieved from http://myjms.mohe.gov.my/index.php/ijbtm

Thouin, M. F., Hoffman, J. J., \& Ford, E. W. (2009). IT outsourcing and firm-level performance: A transaction cost perspective. Information and Management, 46(8), 463-469. https://doi.org/10.1016/j.im.2009.08.006

Undang-Undang. Peraturan Pemerintah No. 20/2008, UU No. 20 Tahun 2008 § (2008).

Waluyo, M. (2016). Mudah cepat tepat penggunaan tools AMOS dalam aplikasi (SEM). (I. Basuki, Ed.). Surabaya: UPN "VETERAN" JAWA TIMUR.

Zhang, Y., Ma, E. (Jintao), \& Qu, H. (2018). Transaction Cost and Resources Based Views on Hotels' Outsourcing Mechanism: An Empirical Study in China. Journal of Hospitality Marketing and Management, 27(5), 583-600. https://doi.org/10.1080/19368623.2018.1406834 


\section{APPENDIX}

Appendix 1. Instrument and Construct Measurement

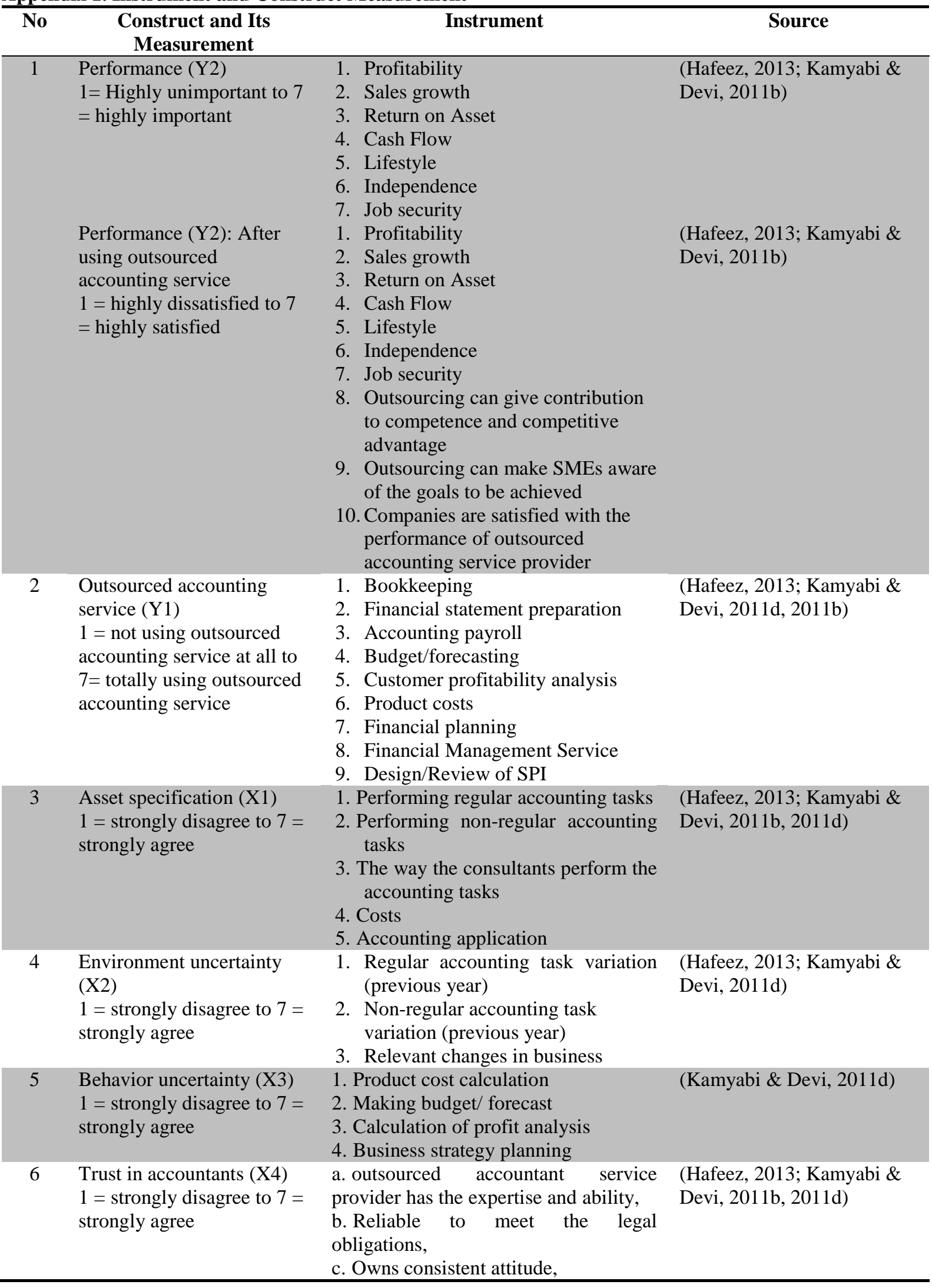




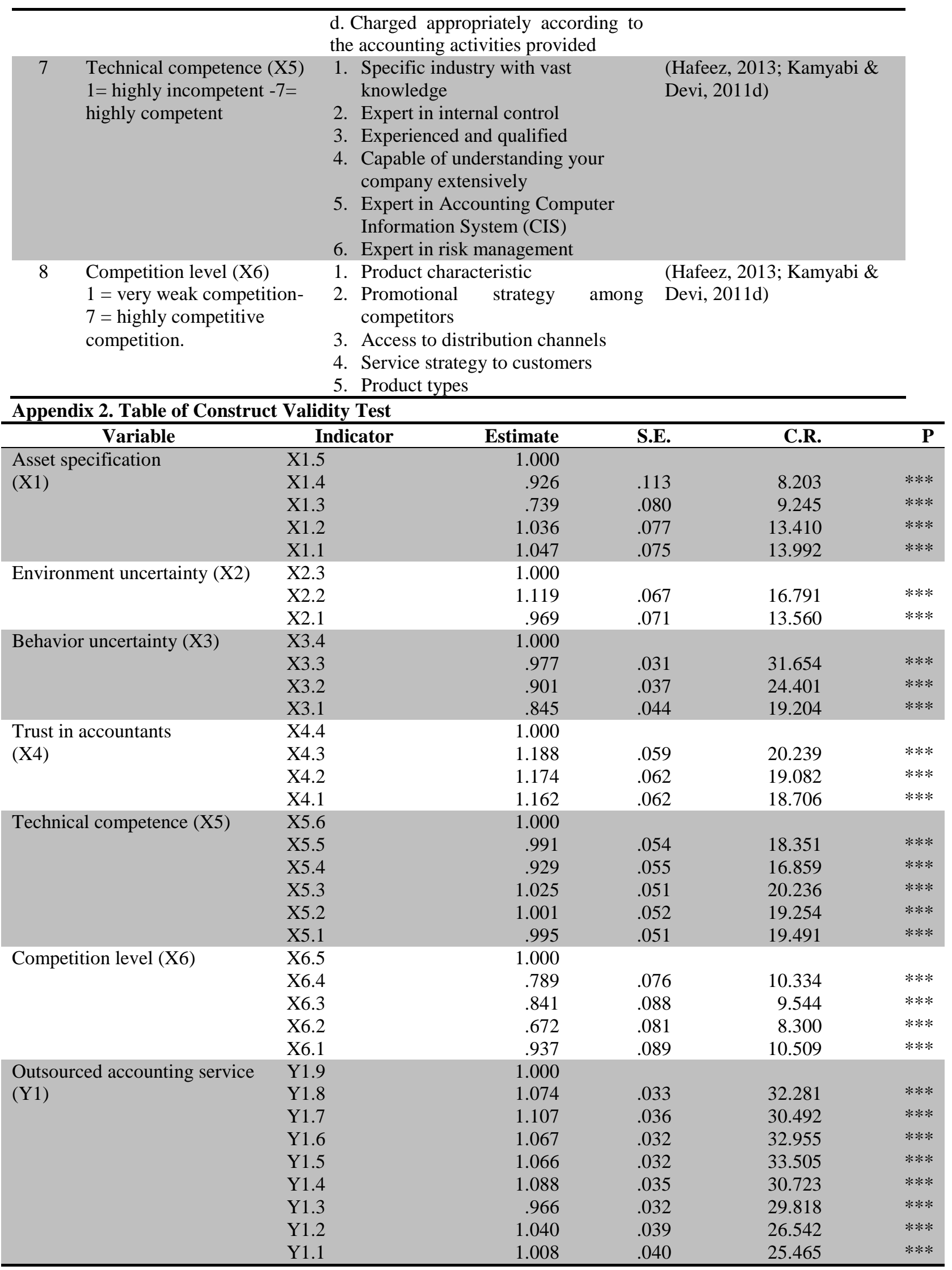




\begin{tabular}{|c|c|c|c|c|c|}
\hline \multirow[t]{17}{*}{ SME performance (Y2) } & Y2.17 & 1.000 & & & \\
\hline & Y2.16 & 1.053 & .021 & 49.446 & $* * *$ \\
\hline & Y2.15 & 1.031 & .022 & 47.224 & $* * *$ \\
\hline & Y2.14 & .990 & .022 & 44.532 & $* * *$ \\
\hline & Y2.13 & .935 & .029 & 32.528 & $* * *$ \\
\hline & Y2.12 & 1.058 & .022 & 47.109 & $* * *$ \\
\hline & Y2.11 & 1.044 & .022 & 48.058 & $* * *$ \\
\hline & Y2.10 & .964 & .021 & 46.669 & $* * *$ \\
\hline & Y2.9 & .983 & .022 & 45.266 & $* * *$ \\
\hline & Y2.8 & 1.003 & .023 & 44.469 & $* * *$ \\
\hline & Y 2.7 & -.030 & .027 & -1.138 & .255 \\
\hline & Y2.6 & .314 & .074 & 4.255 & $* * *$ \\
\hline & Y2.5 & -.060 & .043 & -1.386 & .166 \\
\hline & Y2.4 & -.037 & .030 & -1.236 & .217 \\
\hline & Y2.3 & .004 & .031 & .119 & 906 \\
\hline & Y2.2 & -.036 & .019 & -1.870 & .062 \\
\hline & Y2.1 & -.065 & .022 & -2.908 & .004 \\
\hline
\end{tabular}

Note: $* * * p=0.001$

Appendix 3. Table Hasil Reliability test

\begin{tabular}{lcc}
\hline \multicolumn{1}{c}{ Variable } & CR & AVE \\
\hline Asset specification (X1) & 0.981415301 & 0.9146204 \\
Environment uncertainty (X2) & 1.02045262 & 1.063707333 \\
Ketdakpastian Perilaku (X3) & 0.963864292 & 0.87008875 \\
Trust in accountants (X4) & 1.058978682 & 1.284966 \\
Technical competence (X5) & 0.996830436 & 0.9812955 \\
Competition level (X6) & 0.93057166 & 0.731871 \\
Accounting Outsourcing (Y1) & 1.009890729 & 1.096481556 \\
SME performance (Y2) & 0.991352168 & 0.923347 \\
\hline
\end{tabular}

